31 травня 1990 р. Сергій Іванович Сердюк пішов із життя, залишивши після себе плеяду учнів, які надалі продовжували удосконалювати та впроваджувати у виробництво його наукові ідеї.

УДК 615.012:582.949.2:581.3

DOI 10.32900/2312-8402-2021-125-18-29

\title{
THE ANTIBACTERIAL EFFICACY OF ETHANOL EXTRACTS OBTAINED FROM LEAVES OF SOME THYMUS SPECIES (LAMIACEAE) AGAINST STAPHYLOCOCCUS AUREUS SUBSP. AUREUS STRAIN
}

\author{
Kurhaluk N., Doctor of Biological Sciences \\ https://orcid.org/0000-0002-4669-1092 \\ Tkachenko H., Doctor of Biological Sciences \\ https://orcid.org/0000-0003-3951-9005 \\ Institute of Biology and Earth Sciences, Pomeranian University in Słupsk, Poland \\ Honcharenko V., Ph.D. https://orcid.org/0000-0001-6888-2124 \\ Nachychko V., Ph.D. https://orcid.org/0000-0001-6756-2823 \\ Prokopiv A., Ph.D. https://orcid.org/0000-0003-1690-4090 \\ Ivan Franko National University of Lviv, Ukraine \\ Botanical Garden of National Ivan Franko University of Lviv, Ukraine \\ Aksonov Y. https://orcid.org/0000-0002-6292-7819 \\ The Institute of Animal Science NAAS, Kharkiv, Ukraine
}

A convincing number of investigations that indicate that thymol with other metabolites exhibited potent antimicrobial, antifungal, antibacterial, and antiparasitic properties prompted us to verify the antibacterial efficacy of four species and one interspecific hybrid of the Thymus genus collected in the western part of Ukraine against Staphylococcus aureus subsp. aureus (ATCC ${ }^{\circledR} 29213^{\text {TM})}$ strain. Considering the points highlighted above and based on previous results obtained in our laboratory, in the current study, we decided to evaluate the antimicrobial efficacy of five ethanol extracts obtained from leaves of Thymus representatives against Staphylococcus aureus subsp. aureus (ATCC ${ }^{\circledR} 29213^{\mathrm{TM})}$ strain. Fresh leaves were washed, weighed, crushed, and homogenized in $96 \%$ ethanol (in proportion 1:19) at room temperature. The extracts were then filtered and investigated for their antimicrobial activity. Antimicrobial activity was determined using the agar disk diffusion assay. The ethanol extracts obtained from leaves of Thymus plants showed different antibacterial activities against Staphylococcus aureus subsp. aureus $\left(A T C C^{\circledR} 29213^{\mathrm{TM}}\right)$ strain. The antibacterial activity of extracts was greatest for Th. serpyllum followed by Th. pannonicus followed by Th. pulegioides, Th. alpestris, and then by Th. $x$ porcii. Since the antibacterial effectiveness of medicinal plants varies dramatically depending on the phytochemical characteristics of plant families and subfamilies, it is not surprising to note the difference in this efficacy even when using samples taken from the same plant, but from two different regions. The antimicrobial activity of the crude ethanol extracts obtained from leaves of Thymus plants may be attributed to specific compounds or a combination of compounds. The present study lays the basis for future research, to validate the possible use of Thymus species as a candidate in the treatment of infections caused by Staphylococcus aureus in medicine and veterinary. 
Keywords: Thymus species, leaves, ethanol extracts, Staphylococcus aureus subsp. aureus (ATCC ${ }^{\circledR}$ 29213 $^{\mathrm{TM}}$ ) strain, antimicrobial activity, agar disk diffusion technique

Staphylococcus aureus is highly pathogenic and can cause diseases in both humans and domestic animals. In animals, including ruminants, S. aureus and coagulasenegative staphylococci (CNS) may cause severe or sub-clinical mastitis and intramammary infection in dairy cattle $[6,15,16]$. Moreover, S. aureus ability to generate biofilm is considered an important virulence feature in the pathogenesis of mastitis [6]. As noted by Zaatout and co-authors (2020), S. aureus ability to persist inside the udder is based on the presence of important mechanisms, i.e. its ability to form biofilms, polysaccharide capsules small colony variants, and its ability to invade professional and nonprofessional cells, which will protect $S$. aureus from the innate and adaptive immune response of the cow, and from antibiotics that are no longer considered to be sufficient against $S$. aureus bovine mastitis [38]. S. aureus is also a lesser-known cause of antibiotic-associated diarrhea, which often presents as enterocolitis with large volumes of watery diarrhea [14].

Antimicrobial properties of medicinal plants are being increasingly reported from different parts of the world. To expand the spectrum of antibacterial agents from natural resources, the genus Thymus belonging to the Lamiaceae family has been selected, because, among plant-based antimicrobials, the antimicrobial activity of Thymus species has been well studied [22]. The Lamiaceae family is one of the biggest plant families among flowering plants, which comprises a wide array of plants with biological and medical applications, consisting of 236 genera with a coverage of more than 7.000 species $[12,36]$. The Lamiaceae species is mainly distracted in Mediterranean regions and a small part of them populated Australia, Southwest Asia, and South America [13]. Phytochemical analysis of the Lamiaceae family has reported the presence of flavonoids, flavones, flavanones, flavonoid glycosides, monoterpenes, diterpenes, triterpenoids, essential oil, and fatty acids [34].

The genus Thymus, one of the most consequential genera belonging to the Lamiaceae family, consists of more than 336 species of aromatic perennial herbaceous plants with valuable medicinal properties $[3,35]$. These herbaceous perennials and sub-shrubs are distributed in Europe, Northwest Africa, Ethiopia, Asia, and Greenland [2, 20]. Many species of this genus are used in traditional medicine as tonics, carminatives, antitussives, aromatic, expectorant, stomachic, antispasmodic, bronchospasmolytic, diuretic, sedative, diaphoretic, and antiseptics, as well as anti-inflammatory, antioxidant, anthelmintic, hepatoprotective, and antitumor agents [11, 22]. The six major constituents showing variations among Thymus species include thymol, carvacrol, $\gamma$-terpinene, geraniol, linalool, and p-cymene according to the study of the chemical composition and biological properties of essential oils in different species of Thymus [3]. Thymol, and its main natural source, thyme (Thymus vulgaris L.), are employed for their positive antioxidant, anti-inflammatory, local anesthetic, antinociceptive, cicatrizing, antiseptic, antibacterial, and antifungal properties as well as for their beneficial effects on the cardiovascular system [17].

Our previous study has shown that ethanol extracts obtained from leaves of Thymus representatives inhibited intermediate activity against some bacterial strains, i.e. $\beta$-lactamase producing $P$. aeruginosa and Salmonella enteritidis strains [7-9]. Antimicrobial activity was determined using the agar disk diffusion assay. The mean diameter of the inhibition zone for Thymus serpyllum L. was $(11.3 \pm 0.3) \mathrm{mm}$, for Th. pannonicus

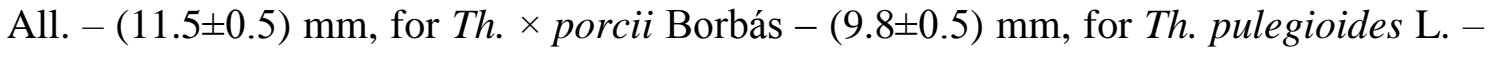


(11.2 \pm 0.7$) \mathrm{mm}$, and for Th. alpestris Tausch ex A. Kern. - (12.8 \pm 0.8$) \mathrm{mm}$. The effects varied significantly according to the Thymus taxa. It should be noted that the most antimicrobial effective plant against $\beta$-lactamase producing $P$. aeruginosa was $T h$. alpestris, being highly active with the ethanol extract (mean diameter of inhibition zone was $12.8 \pm 0.8 \mathrm{~mm}$ ). The antibacterial activity of extracts was greatest for Th. alpestris followed by Th. pannonicus followed by Th. serpyllum and then by Th. pulegioides [8]. The ethanol extract obtained from the leaves of Th. pulegioides were the most effective plant extracts against Salmonella enteritidis strain. The antibacterial activity of extracts was greatest for Th. pulegioides followed by Th. pannonicus $(13.1 \pm 0.85 \mathrm{~mm})$ followed by Th. alpestris $(12.6 \pm 0.25 \mathrm{~mm}), T h . x$ porcii $(12.2 \pm 0.55 \mathrm{~mm})$, and then by $T h$. serphyllum $(10.5 \pm 0.23 \mathrm{~mm})$. These plant extracts could be a potential source of new antibacterial agents [7].

A persuasive number of investigations that indicate that thymol with other metabolites exhibited potent antimicrobial, antifungal, antibacterial, and antiparasitic properties prompted us to verify the antibacterial efficacy of four species and one interspecific hybrid of the Thymus genus sampled in the western part of Ukraine against Staphylococcus aureus strain. Considering the points highlighted above and based on previous results obtained in our laboratory, in the current study, we decided to evaluate the antimicrobial efficacy of five ethanol extracts obtained from leaves of Thymus representatives against Staphylococcus aureus subsp. aureus $\left(\right.$ ATCC $^{\circledR} 29213^{\mathrm{TM}}$ ) strain.

Materials and methods. Collection of Plant Materials. Samples were harvested in June-August, 2016. Leaves of Thymus serpyllum L. emend. Mill. were collected among the grass on sandy soil in the edge of a pine forest (Baymaky village, Bilohirya

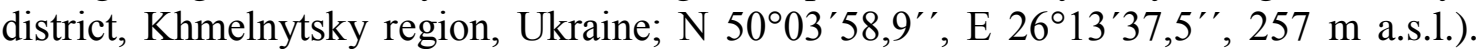
Leaves of Th. pannonicus All. were harvested among grass in the roadside between the two cultivated fields (Syvky village, Bilohirya district, Khmelnytsky region, Ukraine; N $50^{\circ} 02^{\prime} 09,6^{\prime \prime}$, E $26^{\circ} 13^{\prime} 19,2^{\prime \prime}, 283$ m a.s.1.). Leaves of Th. pulegioides L. were collected among grass nearby land parcels (Syvky village, Bilohirya district, Khmelnytsky region, Ukraine; N 50 $02^{\prime} 02,8^{\prime \prime}$, E $26^{\circ} 14^{\prime} 13,9^{\prime \prime}, 306$ m a.s.1.). Leaves of Th. × porcii Borbás (a hybrid between Th. pannonicus and Th. pulegioides) were sampled in the grass stand, on the side of the footpath of the race track (Medovoi Pechery Str., Lviv, Ukraine; N $49^{\circ} 49^{\prime} 15.1^{\prime \prime}$, E $24^{\circ} 05^{\prime} 12.5^{\prime \prime}, 348 \mathrm{~m}$ a.s.1.). Leaves of Th. alpestris Tausch ex A. Kern. were harvested on the side of the road below the stream, in mountain valley Shumneska (Kvasy village, Rakhiv district, Zakarpattia region, Ukraine; N 48 09'32.3", E $24^{\circ} 21^{\prime} 26.4^{\prime \prime}, 1259 \mathrm{~m}$ a.s.1.). Identification of these five taxa was made according to Nachychko $(2014,2015)$ and Nachychko and Honcharenko (2016) [23-25]. The voucher herbarium specimens of plants used in this study were deposited at the Herbarium of M.G. Kholodny Institute of Botany of the National Academy of Sciences of Ukraine (KW). Plant samples were thoroughly washed to remove all attached material and used to prepare ethanol extracts. This study was carried out during the Scholarship Program supported by The Visegrad Fund in the Department of Zoology and Animal Physiology, Institute of Biology and Earth Sciences, Pomeranian University in Słupsk (Poland).

Preparation of Plant Extracts. Fresh leaves were washed, weighed, crushed, and homogenized in $96 \%$ ethanol (in proportion 1:19) at room temperature. The extracts were then filtered and investigated for their antimicrobial activity.

Plant Extracts by the Disk Diffusion Method. Staphylococcus aureus subsp. aureus Rosenbach (ATCC ${ }^{\circledR} 29213^{\mathrm{TM}}$ ) strain, sensitive to oxacillin, was used for the current study. Strain tested was plated on TSA medium (Tryptone Soy Agar) and incubated for $24 \mathrm{~h}$ at $25^{\circ} \mathrm{C}$. Then the suspension of microorganisms was suspended in sterile PBS and the turbidity adjusted equivalent to that of a $0.5 \mathrm{McFarland}$ standard. The antimi- 
crobial activity of extracts was evaluated by using the agar well diffusion method [4]. Muller-Hinton agar plates were inoculated with $200 \mu 1$ of standardized inoculum $\left(10^{8}\right.$ $\mathrm{CFU} / \mathrm{mL}$ ) of the bacterium and spread with sterile swabs. Sterile filter paper discs impregnated by extract were applied over each of the culture plates, $15 \mathrm{~min}$ after bacteria suspension was placed. The antimicrobial susceptibility testing was done on MullerHinton agar by the disc diffusion method (Kirby-Bauer disk diffusion susceptibility test protocol). A negative control disc impregnated by sterile ethanol was used in each experiment. After culturing bacteria on Mueller-Hinton agar, the disks were placed on the same plates and incubated for $24 \mathrm{~h}$ at $37^{\circ} \mathrm{C}$. The assessment of antimicrobial activity was based on the measurement of the diameter of the inhibition zone formed around the disks.

Statistical analysis. The diameters of the inhibition zones were measured in millimeters and compared with those of the control and standard susceptibility disks. The activity was evidenced by the presence of a zone of inhibition surrounding the well. Each test was repeated eleven times. All statistical calculation was performed on separate data from each species with STATISTICA 8.0 (StatSoft, Poland) [39]. The following zone diameter criteria were used to assign susceptibility or resistance of bacteria to the phytochemicals tested: Susceptible $(\mathrm{S}) \geq 15 \mathrm{~mm}$, Intermediate $(\mathrm{I})=11-14 \mathrm{~mm}$, and Resistant $(\mathrm{R}) \leq 10 \mathrm{~mm}[26]$.

Results. To identify Thymus species with antibiotic properties against $S$. aureus strain, the four species and one interspecific hybrid of the Thymus genus were tested using the disk-agar method (Fig. 1). Ethanol (96\%) as the negative control showed inhibition zones of the test strain $(9.9 \pm 0.81 \mathrm{~mm})$. Of the herbal extracts tested, all leaf extracts obtained from Thymus species were found to have antibacterial activity against S. aureus strain tested; inhibition zones ranged from 8.5 to $17 \mathrm{~mm}$. Moreover, Th. serpyllum extract exhibited intermediate antibacterial activity against $S$. aureus with statistically significant diameters of inhibition zones $(15.40 \pm 0.95 \mathrm{~mm})$. The inhibition zones produced by leaf extracts obtained from Th. pannonicus and Th. pulegioides indicated that both showed effective antimicrobial activities, although these extracts showed slightly higher activity, based on inhibition zone sizes $(12.85 \pm 0.99 \mathrm{~mm}$ and $12.74 \pm 1.2$, respectively), these results were non-significantly ( $p>0.05)$. Also, the inhibition zones produced by leaf extracts obtained from Th. alpestris and Th. $x$ porcii indicated that both showed mild activity, based on inhibition zone sizes $(11.65 \pm 1.1 \mathrm{~mm}$ and $11.23 \pm 1.12$, respectively), these results were non-significantly ( $p>0.05)$ (Fig. 1).

It should be noted that the most antimicrobial effective plant against Staphylococcus aureus subsp. aureus $\left(\mathrm{ATCC}^{\circledR} 29213^{\mathrm{TM}}\right.$ ) strain was Th. serpyllum, being highly active with the mean diameter of inhibition zone $15.40 \pm 0.95 \mathrm{~mm}$. The antibacterial activity of extracts was greatest for Th. serpyllum followed by $T h$. pannonicus $(12.85 \pm 0.99 \mathrm{~mm})$ followed by Th. pulegioides $(12.74 \pm 1.2 \mathrm{~mm})$, Th. alpestris $(11.65 \pm 1.1$ $\mathrm{mm})$, and then by Th. x porcii $(11.23 \pm 1.12 \mathrm{~mm}$ ) (Fig. 1). The percent of the increase of inhibition zone diameters formed around discs impregnated by different extracts compared to controls $(96 \%$ ethanol) was as follows, i.e. $55.6 \%(\mathrm{p}<0.05)$ for Th. serpyllum, $29.8 \%(\mathrm{p}>0.05)$ for Th. pannonicus, $28.7 \%(\mathrm{p}>0.05)$ for Th. pulegioides, $17.7 \%$ ( $p>0.05$ ) for Th. alpestris, and $13.4 \%$ ( $p>0.05$ ) for Th. $x$ porcii (Fig. 1). Since the antibacterial effectiveness of medicinal plants varies dramatically depending on the phytochemical characteristics of plant families and subfamilies, it is not surprising to note the difference in this efficacy even when using samples taken from the same plant, but from two different regions. 
18

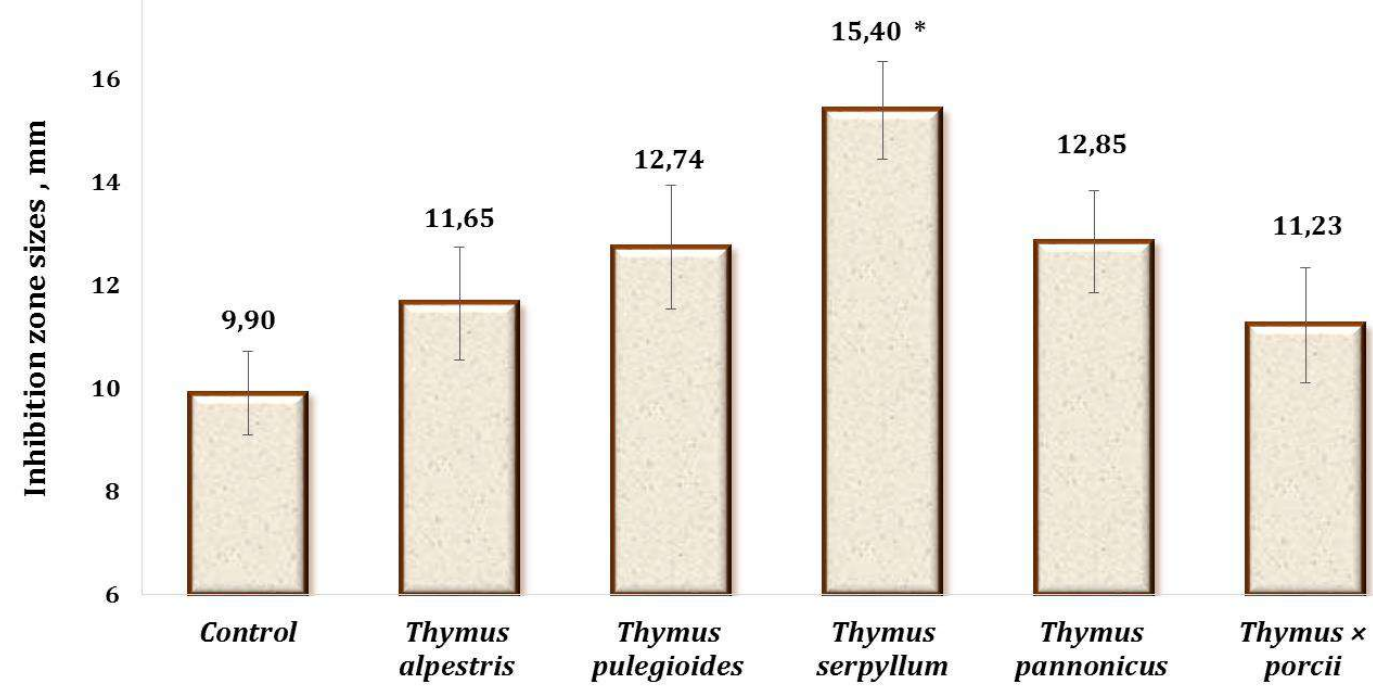

Fig. 1. The mean of inhibition zone diameters of ethanol extracts obtained from leaves of various Thymus plants against Staphylococcus aureus subsp. aureus Rosenbach (ATCC ${ }^{\circledR}$ 29213 $^{\text {TM}}$ ) strain.

* - the changes are statistically significant $(\mathrm{p}<0.05)$ compared to the control group $(96 \%$ ethanol $)(\mathrm{M} \pm \mathrm{m}, \mathrm{n}=11)$.

The antimicrobial activity of the Thymus species has been well studied. Many in vitro studies have shown that thymol possesses antibacterial and antifungal properties. A study conducted by Marino and co-authors (1999) has evaluated the antibacterial activity of essential oils obtained from Th. vulgaris against both Gram-negative bacteria (E. coli, E. coli O157:H7, Proteus mirabilis, P. vulgaris, S. typhimurium, Serratia marcescens, Yersinia enterocolitica, P. fluorescens, P. putida) and Gram-positive (Micrococcus spp., Sarcina flava, S. aureus, Bacillus licheniformis, B. thuringiensis, Listeria innocua) using a bioimpedance method. The results showed that all the thyme essential oils had bacteriostatic activities against the microorganisms [18].

$\mathrm{Xu}$ and co-authors $(2008)$ have revealed that thymol $(200 \mathrm{mg} / \mathrm{ml})$ inhibited the growth of Escherichia coli by inducing the permeabilization and depolarization of the cytoplasmic membrane [37]. A report from Palaniappan and Holley (2010) revealed that thymol at $2.5 \mathrm{mM}$ inhibits the growth of Staphylococcus aureus, E. coli, and Salmonella typhimurium. Thymol and carvacrol were found to be highly effective in reducing the resistance of S. typhimurium SGI 1 (tet A) to ampicillin, tetracycline, penicillin, bacitracin, erythromycin, and novobiocin and resistance of Streptococcus pyogenes ermB to erythromycin. With E. coli N00 666, thymol and cinnamaldehyde were found to have a similar effect in reducing the minimum inhibition concentrations (MIC's) of ampicillin, tetracycline, penicillin, erythromycin, and novobiocin. Carvacrol, thymol, and cinnamaldehyde were effective against $S$. aureus blaZ and in reducing the MIC's of ampicillin, penicillin, and bacitracin [27]. The antibacterial activity of fourteen esters of thymol and carvacrol and their esters against four Gram-positive (Streptococcus mutans MTCC 890, Staphylococcus aureus MTCC 96, Bacillus subtilis MTCC 121, Staphylococcus epidermidis MTCC 435) and one Gram-negative (Escherichia coli MTCC 723) bacteria were screened by Mathela and co-authors (2010). These authors demonstrated that thymol ester derivatives were found to be more effective against Streptococcus species [19]. Thymol was found to possess antibacterial activity against selected verocytotoxigenic E. coli strains and other bacterial species and spoilage bacteria [30]. The study 
of Pemmaraju and co-authors (2013) demonstrated the synergistic effect of terpenes (eugenol, menthol, and thymol) with fluconazole on Candida albicans biofilm, which could be future medications for biofilm infections. Thymol $(0.12 \%)$ possesses antifungal activity against $C$. albicans MTCC 227 biofilm inhibition [28]. Gelatin films containing different thymol concentrations (1-8\%) produced inhibitory zones ranging from 30 to $46 \mathrm{~mm}$ against several bacteria and could be used as a safe and effective source of natural antioxidant and antimicrobial agents with their potential use as modern nanowound dressing against wounds burn pathogens. Thymol was more effective against Gram-positive strains. The antibacterial activity of the films containing thymol was greatest against Staphylococcus aureus followed by Bacillus subtilis followed by Escherichia coli and then Pseudomonas aeruginosa [10]. Thymol derivative named benzoylthymol was the best inhibitor against Leishmania infantum chagasi both in vitro and in vivo study, and acetyl-thymol was more active than thymol and the positive control drug amphotericin B [5].

The thyme essential oils were tested for their inhibitory effects against both Gram-negative (Escherichia coli, E. coli O157:H7, Proteus mirabilis, P. vulgaris, Salmonella typhimurium, Serratia marcescens, Yersinia enterocolitica, Pseudomonas fluorescens, P. putida) and Gram-positive (Micrococcus spp., Sarcina flava, Staphylococcus aureus, Bacillus licheniformis, B. thuringiensis, Listeria innocua) bacteria by Marino and co-authors (1999) using a bioimpedance method [18]. All the thyme essential oils examined had significant bacteriostatic activity against the microorganisms tested. This activity was more marked against the gram-positive bacteria. The oil from thyme in full flower was the most effective at stopping the growth of the microbial species examined. The oils tested were also shown to have good antibacterial activity by direct contact, which appeared to be more marked against the Gram-negative bacteria. Only a few of the species were capable of recovering at least $50 \%$ of their metabolic function after contact with the inhibitor, while most of the strains were shown to have been inactivated almost completely. Escherichia coli O157:H7 was the most sensitive species, given that after contact with even the lowest concentration of oil cells could not be recovered [18].

Rosmarinus officinalis, Thymus capitatus, Origanum majorana, and Salvia officinalis essential oils have shown promising antibacterial activities against reference bacterial strains responsible for nosocomial diseases and foodborne illnesses. Moumni and co-authors (2020) have investigated the correlation between the chemical composition and the antibacterial effect of five essential oils of some Lamiaceae species essential oils against five reference bacterial strains (Pseudomonas aeruginosa, Escherichia coli, Salmonella enterica, Bacillus subtilis, and Staphylococcus aureus) responsible for nosocomial diseases and foodborne illnesses. The different component contents varied according to the species. The main components were carvacrol, 1,8-cineole, $\alpha$-thujone, $\alpha$ terpineol, and $\alpha$-pinene. The PCA and the HCA of the selected essential oil components and the inhibition zone diameter (IZD) values identified four species groups and subgroups. Each essential oils group constituted a chemotype responsible for their bacterial inhibition ability. Thymus capitatus essential oil showed the strongest antibacterial activity with $\mathrm{MBC}$ ranging from 0.73 to $2.94 \mathrm{mg} \mathrm{mL}^{-1}$ [21].

The antibacterial and antioxidant activities of chitosan edible films incorporated with organic essential oils obtained from four Thymus species (Thymus zygis, Thymus mastichina, Thymus capitatus, and Thymus vulgaris) were evaluated by Ballester-Costa and co-authors (2016). The agar disc diffusion method was used to determine the antibacterial activities of chitosan edible films while for the antioxidant activity, two different analytical assays were used (DPPH and FRAP). As regard antibacterial activity, 
films containing the only chitosan were not effective against any of the tested bacteria. Chitosan films containing $T$. capitatus essential oil (EO) (CH+TCEO) were more effective against Listeria innocua and Alcaligenes faecalis whilst chitosan films containing T. mastichina essential oil (CH+TMEO) had the highest inhibition halos against Serratia marcescens. For and Enterobacter amnigenus no antibacterial activity was achieved. Chitosan films added with Thymus essential oils showed antioxidant activity, at all concentrations and with all methods assayed. $\mathrm{CH}+\mathrm{TZEO}$ had the highest antioxidant activity revealed with the DPPH assay. However, CH+TCEO showed the best antioxidant effect when assessed with FRAP assay. The results showed that chitosan edible films incorporated with organic Thymus essential oils could be used as active films in the food industry due to their antibacterial and antioxidant activities [1].

Oregano oil, thyme oil, carvacrol, and thymol showed well in vitro bactericidal and fungicidal activity against 100 isolates from dogs with otitis externa, including some highly drug-resistant isolates. These essential oils and their main phenolic constituents have the potential to be further investigated in vivo for the treatment of canine otitis externa. In vitro efficacy of oregano oil, thyme oil, and their main phenolic constituents against bacterial and fungal isolates associated with canine otitis externa were investigated by Sim and co-authors (2019). Antimicrobial susceptibility testing was performed using broth microdilution with spot-plating technique to determine minimum inhibitory and bactericidal/fungicidal concentrations (MICs, MBCs and MFCs). One hundred bacterial and fungal isolates, including meticillin-susceptible Staphylococcus pseudintermedius $(\mathrm{n}=10)$, meticillin-resistant $S$. pseudintermedius $(\mathrm{n}=10), \beta$-hemolytic Streptococcus spp. $(\mathrm{n}=20)$, Pseudomonas aeruginosa $(\mathrm{n}=20$; including 10 isolates resistant to one or two antimicrobials), Proteus mirabilis $(\mathrm{n}=20)$, and Malassezia pachydermatis $(n=20)$ from dogs with otitis externa were used. Results of a study conducted by Sim and co-authors (2019) revealed that oregano oil, thyme oil, carvacrol, and thymol exhibited antibacterial activity against all bacterial and fungal isolates tested. $\mathrm{MIC}_{90}$ values ranged from 0.015 to $0.03 \%(146-292 \mu \mathrm{g} / \mathrm{mL})$ for the Gram-positive bacteria and $P$. mirabilis. For $P$. aeruginosa and $M$. pachydermatis, $\mathrm{MIC}_{90}$ values ranged from 0.09 to $0.25 \%(800-2,292 \mu \mathrm{g} / \mathrm{mL})[33]$.

Another potential application of thyme essential oils could derive from the results of more research showing its antibacterial activity against Streptococcus mutans, one of the primary cariogenic bacterial species. The essential oils of the four Thymus species exhibited antibacterial activity against $S$. mutans in vitro in the study of Schött and co-authors (2017). Rinsing with polyphenol-rich infusions reduced the initial bacterial colonization while the essential oil inhibited the bacterial growth on dental enamel in situ [32]. The two main bioactive compounds in thyme essential oil are thymol and carvacrol responsible for most therapeutic aspects of the thyme extracts, i.e. antibacterial, antifungal, anti-inflammatory, and antioxidant activities [29]. In a study by Rota and co-authors (2008), most of the antimicrobial activity in essential oils from the Thymus genus appears to be associated with phenolic compounds (thymol and carvacrol) [31]. Schött and co-authors (2017) have identified 69 volatile compounds in the ethyl acetate extracts, and 49 polyphenols in the aqueous infusion [32]. The comprehensive examinations of the essential oil and the polyphenols in four pharmacologically active Thymus species (Th. vulgaris, Th. zygis, Th. serpyllum, and Th. pulegioides) revealed that the main components in both, volatile compounds and polyphenols, were equal. All investigated Thymus species contained thymol for the volatile compounds and rosmarinic acid or luteolin-glucuronide for the polyphenols as major constituents. Further characteristic volatile compounds were p-cymene, $\gamma$-terpinene, $\beta$-linalool, carvacrol, and $\beta$ caryophyllene [32]. 
Conclusions. The ethanol extracts obtained from leaves of studied Thymus representatives showed different antibacterial activities against Staphylococcus aureus subsp. aureus Rosenbach $\left(\right.$ ATCC $^{\circledR} 29213^{\mathrm{TM}}$ ) strain. The antibacterial activity of extracts was greatest for Th. serpyllum followed by Th. pannonicus followed by Th. pulegioides, Th. alpestris, and then by Th. x porcii. Since the antibacterial effectiveness of medicinal plants varies dramatically depending on the phytochemical characteristics of plant families and subfamilies, it is not surprising to note the difference in this efficacy even when using samples taken from the same plant, but from two different regions. The antimicrobial activity of the crude ethanol extracts obtained from leaves of Thymus plants may be attributed to a specific compound or a combination of compounds. The knowledge about the chemical profile of the extract helps in explaining the observed activity and designing experiments for activity fractionation for isolation of the active principle.

\section{References}

1. Ballester-Costa, C., Sendra, E., Fernández-López, J., \& Viuda-Martos, M. (2016). Evaluation of the antibacterial and antioxidant activities of chitosan edible films incorporated with organic essential oils obtained from four Thymus species. J. Food Sci. Technol., 53 (8), 3374-3379. https://doi.org/10.1007/s13197-016-2312-y.

2. Bartolucci, F., Peruzzi, L., \& Passalacqua, N. (2013). Typification of names and taxonomic notes within the genus Thymus L. (Lamiaceae). Taxon, 62 (6), 13081314.

3. Basch, E., Ulbricht, C., Hammerness, P., Bevins, A., \& Sollars, D. (2004). Thyme (Thymus vulgaris L.), thymol. J. Herb Pharmacother., 4 (1), 49-67.

4. Bauer, A. W., Kirby, W. M., Sherris, J. C., \& Turck, M. (1966). Antibiotic susceptibility testing by a standardized single disk method. Am. J. Clin. Pathol., 45 (4), 493-496.

5. De Morais, S. M., Vila-Nova, N. S., Bevilaqua, C. M., Rondon, F. C., Lobo, C. H., De Alencar Araripe Noronha Moura, A., Sales, A. D., Rodrigues, A. P., De Figuereido, J. R., Campello, C. C., Wilson, M. E., \& De Andrade, H. F. Jr. (2014). Thymol and eugenol derivatives as potential antileishmanial agents. Bioorg. Med. Chem., 22(21), 6250-6255. https://doi.org/10.1016/j.bmc.2014.08.020.

6. Felipe, V., Morgante, C. A., Somale, P. S., Varroni, F, Zingaretti, M. L., Bachetti, R. A., Correa, S. G., \& Porporatto, C. (2017). Evaluation of the biofilm forming ability and its associated genes in Staphylococcus species isolates from bovine mastitis in Argentinean dairy farms. Microb. Pathog., 104, 278-286. https://doi.org/10.1016/j.micpath.2017.01.047.

7. Honcharenko, V., Tkachenko, H., Nachychko, V., Prokopiv, A., \& Osadowski, Z. (2018). The antibacterial activities of some Thymus (Lamiaceae) representatives against Salmonella enteriditis strain locally isolated. Agrobiodiversity for Improving Nutrition, Health, and Life Quality, (2), 212-222. https://doi.org/10.15414/agrobiodiversity.2018.2585-8246.212-222

8. Honcharenko, V., Tkachenko, H., Osadowski, Z., Nachychko, V., \& Prokopiv, A. (2018). The antibacterial activities of ethanolic extracts obtained from leaves of some Thymus (Lamiaceae) representatives against $\beta$-lactamase producing Pseudomonas aeruginosa strain. Stupskie Prace Biologiczne, 15, 59-78.

9. Honcharenko, V., Tkachenko, H., Prokopiv, A., Nachychko, V., Kurhaluk, N., \& Osadowski, Z. (2019). Oxidative stress biomarkers in the equine erythrocytes after In Vitro treated with leaf extract obtained from Thymus $\times$ porcii Borbás (Lamiaceae). Agrobiodiversity for Improving Nutrition, Health, and Life Quality, (3), 382-393. https://doi.org/10.15414/agrobiodiversity.2019.2585-8246.382-393. 
10. Kavoosi, G., Dadfar, S. M., \& Purfard, A. M. (2013). Mechanical, physical, antioxidant, and antimicrobial properties of gelatin films incorporated with thymol for potential use as nano wound dressing. J. Food Sci., 78 (2), E 244-250. https://doi.org/10.1111/1750-3841.12015.

11. Khan, I. A., Abourashed, E. A. (2010). Leung's Encyclopedia of Common Natural Ingredients Used in Food, Drugs and Cosmetics ( $3^{\text {rd }}$ ed.), John Wiley and Sons, Inc., Hoboken, NJ, p. 594-597.

12. Khoury, M., Stien, D., Eparvier, V., Ouaini, N., \& El Beyrouthy, M. (2016). Report on the Medicinal Use of Eleven Lamiaceae Species in Lebanon and Rationalization of Their Antimicrobial Potential by Examination of the Chemical Composition and Antimicrobial Activity of Their Essential Oils. Evid. Based Complement. Alternat. Med., 2016, 2547169. https://doi.org/10.1155/2016/2547169.

13. Kokkini, S., Karousou, R., Hanlidou, E. (2003). HERBS Herbs of the Labiatae, In Encyclopedia of Food Sciences and Nutrition, $2^{\text {nd }}$ ed., Ed. Caballero B., Oxford: Academic Press. https://doi.org/10.1016/B0-12-227055-X/00593-9

14. Larcombe, S., Jiang, J. H., Hutton, M. L., Abud, H. E., Peleg, A. Y., \& Lyras, D. (2020). A mouse model of Staphylococcus aureus small intestinal infection. $J$. Med. Microbiol., 69(2), 290-297. https://doi.org/10.1099/jmm.0.001163.

15. Leuenberger, A., Sartori, C., Boss, R., Resch, G., Oechslin, F., Steiner, A., Moreillon, P., \& Graber, H. U. (2019). Genotypes of Staphylococcus aureus: On-farm epidemiology and the consequences for prevention of intramammary infections. $J$. Dairy Sci., 102(4), 3295-3309. https://doi.org/10.3168/jds.2018-15181.

16. Li, T., Lu, H., Wang, X., Gao, Q., Dai, Y., Shang, J., \& Li, M. (2017). Molecular Characteristics of Staphylococcus aureus Causing Bovine Mastitis between 2014 $\begin{array}{llllll}\text { and 2015. Front Cell Infect. Microbiol., } & 127 .\end{array}$ https://doi.org/10.3389/fcimb.2017.00127.

17. Marchese, A., Orhan, I. E., Daglia, M., Barbieri, R., Di Lorenzo, A., Nabavi, S. F., Gortzi, O., Izadi, M., \& Nabavi, S. M. (2016). Antibacterial and antifungal activities of thymol: A brief review of the literature. Food Chem., 210, 402-414. https://doi.org/10.1016/j.foodchem.2016.04.111.

18. Marino, M., Bersani, C., \& Comi, G. (1999). Antimicrobial activity of the essential oils of Thymus vulgaris L. measured using a bioimpedometric method. J. Food Prot., 62(9), 1017-1023. https://doi.org/10.4315/0362-028x-62.9.1017.

19. Mathela, C. S., Singh, K. K., \& Gupta, V. K. (2010). Synthesis and in vitro antibacterial activity of thymol and carvacrol derivatives. Acta Pol. Pharm., 67(4), 375380.

20. Morales, R. (2002). The history, botany and taxonomy of the genus Thymus. In: Stahl-Biskup E., Sáez F. (Eds.) Thyme. The genus Thymus. Taylor \& Francis, London, New York, p. 1-43.

21. Moumni, S., Elaissi, A., Trabelsi, A., Merghni, A., Chraief, I., Jelassi, B., Chemli, R., \& Ferchichi, S. (2020). Correlation between chemical composition and antibacterial activity of some Lamiaceae species essential oils from Tunisia. BMC Complement. Med. Ther., 20(1), 103. https://doi.org/10.1186/s12906-020-02888-6.

22. Nabavi, S. M., Marchese, A., Izadi, M., Curti, V., Daglia, M., \& Nabavi, S. F. (2015). Plants belonging to the genus Thymus as antibacterial agents: from farm to pharmacy. Food Chem., 173, 339-347. https://doi.org/10.1016/j.foodchem. 2014.10.042.

23. Nachychko, V. (2014). The genus Thymus L. (Labiatae Juss.) in the Ukrainian Carpathians' flora: systematics and taxonomic problems. Visnyk of Lviv University. Biological Series. Lviv, 64, 159-169 [in Ukrainian]. 
24. Nachychko, V. O. (2015). Diagnostic features of representatives of Thymus sect. Serpyllum and T. sect. Marginati (Lamiaceae) and guidance for their herborization. The Journal of V. N. Karazin Kharkiv National University. Series: Biology, 25, 7789.[in Ukrainian].

25. Nachychko, V. O., Honcharenko, V. I. (2016). Hybrids of Thymus L. (Lamiaceae) genus in flora of the western regions of Ukraine: taxonomic composition and distribution. Studia Biologica, 10(1), 163-186. [in Ukrainian].

26. Okoth, D. A., Chenia, H. Y., \& Koorbanally, N. A. (2013). Antibacterial and antioxidant activities of flavonoids from Lannea alata (Engl.) Engl. (Anacardiaceae). Phytochem. Lett., 6, 476-481.

27. Palaniappan, K., Holley, R. A. (2010). Use of natural antimicrobials to increase antibiotic susceptibility of drug resistant bacteria. Int. J. Food Microbiol., 140 (2-3), 164-168. https://doi.org/10.1016/j.ijfoodmicro.2010.04.001.

28. Pemmaraju, S. C., Pruthi, P. A., Prasad, \& R., Pruthi, V. (2013). Candida albicans biofilm inhibition by synergistic action of terpenes and fluconazole. Indian $J$. Exp. Biol., 51(11), 1032-1037.

29. Petrović, N. V., Petrović, S. S., Džamić, A. M., Ćirić, A. D., Ristić, M. S., Milovanović, S. L., \& Petrović, S. D. (2016). Chemical composition, antioxidant and antimicrobial activity of Thymus praecox supercritical extracts. J. Supercrit. Fluids, $110,117-125$.

30. Rivas, L., McDonnell, M. J., Burgess, C. M., O'Brien, M., NavarroVilla, A., Fanning, S., \& Duffy, G. (2010). Inhibition of verocytotoxigenic Escherichia coli in model broth and rumen systems by carvacrol and thymol. Int. J. Food Microbiol., 139(1-2), 70-78. https://doi.org/10.1016/j.ijfoodmicro.2010.01.029.

31. Rota, M. C., Herrera, A., Martínez, R. M., Sotomayor, J. A., \& Jordán, M. J. (2008). Antimicrobial activity and chemical composition of Thymus vulgaris, Thymus zygis and Thymus hyemalis essential oils. Food Control, 19(7), 681-687.

32. Schött, G., Liesegang, S., Gaunitz, F., Gleß, A., Basche, S., Hannig, C., \& Speer, K. (2017). The chemical composition of the pharmacologically active Thymus species, its antibacterial activity against Streptococcus mutans and the antiadherent effects of T. vulgaris on the bacterial colonization of the in situ pellicle. Fitoterapia, 121, 118-128. https://doi.org/10.1016/j.fitote.2017.07.005.

33. Sim, J. X. F., Khazandi, M., Chan, W. Y., Trott, D. J., \& Deo, P. (2019). Antimicrobial activity of thyme oil, oregano oil, thymol and carvacrol against sensitive and resistant microbial isolates from dogs with otitis externa. Vet. Dermatol., 30(6), 524-159. https://doi.org/10.1111/vde.12794.

34. Sim, L. Y., Abd Rani, N. Z., \& Husain, K. (2019). Lamiaceae: An Insight on Their Anti-Allergic Potential and Its Mechanisms of Action. Front Pharmacol., 10, 677. https://doi.org/10.3389/fphar.2019.00677.

35. Soorni, A., Borna, T., Alemardan, A., Chakrabarti, M., Hunt, A. G., \& Bombarely, A. (2019). Transcriptome Landscape Variation in the Genus Thymus. Genes (Basel), 10(8), 620. https://doi.org/10.3390/genes10080620.

36. Uritu, C. M., Mihai, C. T., Stanciu, G. D., Dodi, G., Alexa-Stratulat, T., Luca, A., Leon-Constantin, M. M., Stefanescu, R., Bild, V., Melnic, S., \& Tamba, B. I. (2018). Medicinal Plants of the Family Lamiaceae in Pain Therapy: A Review. Pain Res. Manag., 2018, 7801543. https://doi.org/10.1155/2018/7801543.

37. Xu, J., Zhou, F., Ji, B. P., Pei, R. S., \& Xu, N. (2008). The antibacterial mechanism of carvacrol and thymol against Escherichia coli. Lett. Appl. Microbiol., 47(3), 174-179. https://doi.org/10.1111/j.1472-765X.2008.02407.x. 
38. Zaatout, N., Ayachi, A., \& Kecha, M. (2020). Staphylococcus aureus persistence properties associated with bovine mastitis and alternative therapeutic modalities. J. Appl. Microbiol., 129 (5), 1102-1119. https://doi.org/10.1111/jam.14706. Jersey.

39. Zar, J. H. (1999). Biostatistical Analysis. $4^{\text {th }}$ ed., Prentice Hall Inc., New

АНТИБАКТЕРИАЛЬНАЯ ЭФФЕКТИВНОСТЬ СПИРТОВЫХ ЭКСТРАКТОВ, ПОЛУЧЕННЫХ ИЗ ЛИСТЬЕВ НЕКОТОРЫХ ВИДОВ ТИМЬЯНА (LAMIACEAE), OTHOCИTЕЛЬHO STAPHYLOCOCCUS AUREUS SUBSP. AUREUS

Кургалюк Н., Ткаченко Г., Институт биологии и наук о Земле Поморской академии в Слупске, Польша

Гончаренко В., Национальный университет имени Ивана Франко, Львов, Украина

Начичко В., Прокопив А., Начиональный университет имени Ивана Франко, Львов, Украина. Ботанический сад Национального университета имени Ивана Франко, Львов, Украина

Аксенов Е., Институт животноводства НААН, Харьков, Украина

Убедительное количество исследований, показывающих, что тимол вместе с другими метаболитами проявляет сильные противомикробные, противогрибковые и противопаразитарные свойства, побудило нас проверить антибактериальную эффективность четырех видов и одного межвидового гибрида рода Thyтия, собранных в западной части Украины, относительно итамма Staphylococcus aureus subsp. aureus (ATCC $\left.{ }^{\circledR} 29213^{\mathrm{TM}}\right)$. На основании данных литературы и предыдущих результатах, полученных в нашей лаборатории, в текущем исследовании мы решили проанализировать антимикробную эфффективность пяти спиртовых экстрактов, полученных из листьев представителей тимьяна, относительно Staphylococcus aureus subsp. aureus (ATCC $\left.{ }^{\circledR} 29213^{\mathrm{TM}}\right)$. Cвежие листья промывали, взвешивали, измельчали и гомогенизировали в 96\% этаноле (пропориия 1:19) при комнатной температуре. Затем экстракты фильтровали и исследовали их антимикробную активность используя агаро-диффузионный метод. Этанольные экстракты, полученные из листьев растений тимьяна, показали различную антибактериальную активность в отношении Staphylococcus aureus subsp. aureus (ATCC ${ }^{\circledR} 29213^{\mathrm{TM})}$. Высокую антибактериальную активность проявили экстракты, полученные из листьев Th. serpyllum, затем - Th. pannonicus, Th. pulegioides, Th. alpestris u Th. х рогсіi. Поскольку антибактериальная эффективность лекарственных растений сильно различается в зависимости от фитохимических характеристик семейств и подсемейств растений, неудивительно, что можно заметить разницу в этой эффективности даже при использовании образиов, взятых с одного и того же растения, но из двух разных регионов. Противомикробная активность неочищенных этанольных экстрактов, полученных из листьев растений тимьяна, может быть связана с определенными соединениями или комбинацией соединений с выраженными антибактериальными свойствами. Представленные результаты закладывают основу для будущзих исследований, чтобы подтвердить возможное использование видов Thyтиs в качестве кандидатов для лечения инфекичий, вызванных S. aureus в медицине и ветеринарии.

Ключевые слова: тимьян, листья, спиртовые экстракты, Staphylocoсcиs

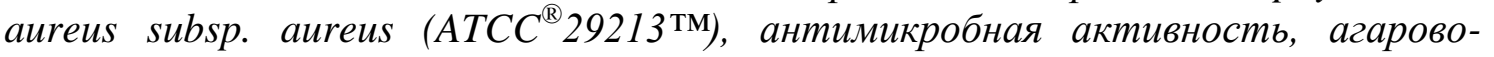
диффузионный метод 


\section{АНТИБАКТЕРІЙНА ЕФЕКТИВНІСТЬ СПИРТОВИХ ЕКСТРАКТІВ, ОТРИМАНИХ 3 ЛИСТЯ ДЕЯКИХ ВИДІВ ЧЕБРЕЦЮ (LAMIACEAЕ) ЩОДО STAPHYLOCOCCUS AUREUS SUBSP. AUREUS}

Кургалюк Н., Ткаченко Г., Інститут біологї̈ та наук про Землю, Поморська Академія в Слупську, Польща

Гончаренко В., Національний університет імені Івана Франка, Львів, Україна

Начичко В., Прокопів А., Наџіональний університет імені Івана Франка, Львів, Україна. Ботанічний сад Національного університету імені Івана Франка, Львів, Україна

Аксьонов С., Інститут тваринництва НААН, Харків, Україна

Переконлива кількість досліджень показала, шуо тимол разом з іншими вторинними метаболітами проявляє сильні антимікробні, антигрибкові та антипаразитарні властивості. Цей факт спонукав нас дослідити антибактерійну ефективність чотирьох видів $і$ одного міжвидового гібриду роду Thyтия, зібраних в західній частині України, щяодо Staphylococcus aureus subsp. aureus $\left(\right.$ АTCC $\left.{ }^{\circledR} 29213^{\mathrm{TM}}\right)$. На підставі даних літератури і попередніх результатів, отриманих в нашій лабораторії, у изьому дослідженні ми вирішили проаналізувати антимікробну ефективність п'яти спиртових екстрактів, отриманих з листя чотирьох видів і одного міжвидового гібриду чебрецюю, щзодо штаму S. аитеиs subsp.

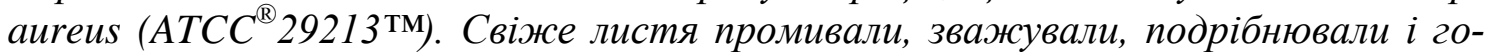
могенізували в 96\% етанолі (пропориія 1:19) при кімнатній температурі. Потім екстракти фільтрували і досліджували їх антимікробну активність за допомогою агаро-дифузійного методу. Етанольні екстракти, отримані з листя рослин чебрецю, показали різну антибактерійну активність щэодо S. aureus subsp. aureus. Найвищу антибактеріальну активність проявили екстракти, отримані з листя Th. serpyllum, Th. pannonicus, nomin - Th. pulegioides, Th. alpestris $i$ Th. $x$ porcii. Оскільки антибактерійна ефективність лікарських рослин сильно відрізняється залежно від фітохімічних характеристик родин і підродин рослин, не дивно, щзо можна помітити різницю в иій ефективності навіть при використанні зразків, взятих з однієї рослини, але з двох різних регіонів. Протимікробна активність неочищених етанольних екстрактів, отриманих з листя рослин чебрецюю, може бути пов'язана з певними сполуками або комбінацією сполукб які проявляють антибактерійну властивість. Це дослідження закладає основу для майбутніх праць, щоб підтвердити можливе використання видів Тhутиs як кандидатів для лікування інфекиій, викликаних S. аитеиз в медицині і ветеринарії.

Ключові слова: чебрець, листя, етанольні екстракти, Staphylocoсcиs aureus subsp. aureus (ATCC $\left.{ }^{\circledR} 29213^{\mathrm{TM}}\right)$, антибактерійна активність, агаро-дифузійний метод. 